\title{
A comprehensive screening of copy number variability in dementia with Lewy bodies
}

Celia Kun-Rodrigues a , Tatiana Orme ${ }^{a, b}$, Susana Carmona ${ }^{a, b}$, Dena G. Hernandez ${ }^{c, d}$, Owen A. Ross ${ }^{\mathrm{e}}$, John D. Eicher ${ }^{\mathrm{f}}$, Claire Shepherd ${ }^{\mathrm{g}}$, Laura Parkkinen ${ }^{\mathrm{h}}$, Lee Darwent ${ }^{\mathrm{b}, \mathrm{a}}$, Michael G. Heckman ${ }^{\mathrm{i}}$, Sonja W. Scholz ${ }^{\mathrm{j}, \mathrm{k}}$, Juan C. Troncoso ${ }^{1}$, Olga Pletnikova ${ }^{1}$, Ted Dawson $^{\mathrm{k}}$, Liana Rosenthal ${ }^{\mathrm{k}}$, Olaf Ansorge ${ }^{\mathrm{h}}$, Jordi Clarimon ${ }^{\mathrm{m}}$, Alberto Lleo ${ }^{\mathrm{m}}$, Estrella Morenas-Rodriguez ${ }^{\mathrm{m}}$, Lorraine Clark ${ }^{\mathrm{n}}$, Lawrence S. Honig ${ }^{\mathrm{n}}$, Karen Marder ${ }^{\mathrm{n}}$, Afina Lemstra ${ }^{\circ}$, Ekaterina Rogaeva ${ }^{\mathrm{p}}$, Peter St. George-Hyslop ${ }^{\mathrm{p}, \mathrm{q}}$, Elisabet Londos ${ }^{\mathrm{r}}$, Henrik Zetterberg ${ }^{\mathrm{s}}$, Imelda Barber ${ }^{t}$, Anne Braae ${ }^{\mathrm{t}}$, Kristelle Brown ${ }^{\mathrm{t}}$, Kevin Morgan ${ }^{\mathrm{t}}$,

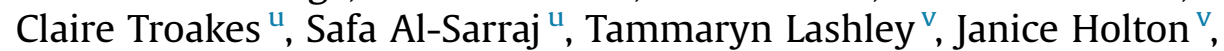
Yaroslau Compta ${ }^{\mathrm{v}, \mathrm{w}}$, Vivianna Van Deerlin ${ }^{\mathrm{x}}$, Geidy E. Serrano ${ }^{\mathrm{y}}$, Thomas G. Beach ${ }^{\mathrm{y}}$, Suzanne Lesage ${ }^{\mathrm{z}}$, Douglas Galasko ${ }^{\mathrm{a}}$, Eliezer Masliah ${ }^{\mathrm{bb}}$, Isabel Santana ${ }^{\mathrm{cc}}$, Pau Pastor $^{\text {dd }}$, Monica Diez-Fairen ${ }^{\text {dd }}$, Miquel Aguilar ${ }^{\text {dd }}$, Pentti J. Tienari ${ }^{\text {ee }}$, Liisa Myllykangas ${ }^{\mathrm{ff}}$, Minna Oinas ${ }^{\mathrm{gg}}$, Tamas Revesz ${ }^{\mathrm{v}}$, Andrew Lees ${ }^{\mathrm{v}}$, Brad F. Boeve ${ }^{\mathrm{h}}$, Ronald C. Petersen $^{\text {hh }}$, Tanis J. Ferman ${ }^{\mathrm{ii}}$, Valentina Escott-Price ${ }^{\mathrm{jj}}$, Neill Graff-Radford ${ }^{\mathrm{k} k}$, Nigel J. Cairns ${ }^{11}$, John C. Morris ${ }^{11}$, Stuart Pickering-Brown ${ }^{\mathrm{mm}}$, David Mann ${ }^{\mathrm{mm}}$, Glenda M. Halliday ${ }^{g, n n}$, John Hardy ${ }^{a}$, John Q. Trojanowski ${ }^{\mathrm{x}}$, Dennis W. Dickson ${ }^{\mathrm{e}}$, Andrew Singleton ${ }^{c}$, David J. Stone ${ }^{\text {oo }}$, Rita Guerreiro ${ }^{\mathrm{a}, \mathrm{b}, \mathrm{pp}}$, Jose Bras ${ }^{\mathrm{a}, \mathrm{b}, \mathrm{pp}, *}$

\footnotetext{
a Department of Neurodegenerative Disease, UCL Institute of Neurology, London, UK

${ }^{\mathrm{b}}$ UK Dementia Research Institute (UK DRI) at UCL, London, UK

${ }^{c}$ Laboratory of Neurogenetics, National Institutes on Aging, NIH, Bethesda, MD, USA

${ }^{\mathrm{d}}$ German Center for Neurodegenerative Diseases (DZNE), Tubingen, Germany

e Department of Neuroscience, Mayo Clinic, Jacksonville, FL, USA

${ }^{\mathrm{f}}$ Genetics and Pharmacogenomics, Merck Research Laboratories, Boston, MA, USA

${ }^{\mathrm{g}}$ Neuroscience Research Australia, Sydney, Australia and School of Medical Sciences, Faculty of Medicine, University of New South Wales, Sydney, Australia

${ }^{\mathrm{h}}$ Nuffield Department of Clinical Neurosciences, Oxford Parkinsons Disease Centre, University of Oxford, Oxford, UK

${ }^{\mathrm{i}}$ Division of Biomedical Statistics and Informatics, Mayo Clinic, Jacksonville, FL, USA

${ }^{\mathrm{j}}$ Neurodegenerative Diseases Research Unit, National Institute of Neurological Disorders and Stroke, National Institutes of Health, Bethesda, MD, USA

${ }^{\mathrm{k}}$ Department of Neurology, Johns Hopkins School of Medicine, Baltimore, MD, USA

${ }^{1}$ Department of Pathology (Neuropathology), Johns Hopkins University School of Medicine, Baltimore, MD, USA

$\mathrm{m}$ Memory Unit, Department of Neurology, IIB Sant Pau, Hospital de la Santa Creu i Sant Pau, Universitat Autonoma de Barcelona, Barcelona, Spain; Centro de Investigacion Biomedica en Red en Enfermedades Neurodegenerativas (CIBERNED), Instituto de Salud Carlos III, Madrid, Spain

${ }^{\mathrm{n}}$ Taub Institute for Alzheimer Disease and the Aging Brain and Department of Pathology and Cell Biology, Columbia University, New York, NY, USA ${ }^{\circ}$ Department of Neurology and Alzheimer Center, Neuroscience Campus Amsterdam, VU University Medical Center, Amsterdam, The Netherlands

${ }^{\mathrm{p}}$ Tanz Centre for Research in Neurodegenerative Diseases and Department of Medicine, University of Toronto, Ontario, Canada

${ }^{\mathrm{q}}$ Department of Clinical Neurosciences, Cambridge Institute for Medical Research, University of Cambridge, Cambridge, UK

${ }^{r}$ Clinical Memory Research Unit, Institution of Clinical Sciences Malmo, Lund University, Lund, Sweden

${ }^{s}$ UK Dementia Research Institute at UCL, London UK, Department of Molecular Neuroscience, UCL Institute of Neurology, London, UK and Clinical Neurochemistry Laboratory, Institute of Neuroscience and Physiology, Sahlgrenska Academy at the University of Gothenburg, Molndal, Sweden

${ }^{\mathrm{t}}$ Human Genetics, School of Life Sciences, Queens Medical Centre, University of Nottingham, Nottingham, UK

${ }^{u}$ Department of Basic and Clinical Neuroscience and Institute of Psychiatry, Psychology and Neuroscience, Kings College London, London, UK

${ }^{\vee}$ Queen Square Brain Bank, Department of Molecular Neuroscience, UCL Institute of Neurology, London, UK

${ }^{w}$ Queen Square Brain Bank, Department of Molecular Neuroscience, UCL Institute of Neurology, London, UK and Movement Disorders Unit, Neurology Service, Clinical Neuroscience Institute (ICN), Hospital Clinic, University of Barcelona, IDIBAPS, Barcelona, Spain

${ }^{\mathrm{x}}$ Department of Pathology and Laboratory Medicine, Center for Neurodegenerative Disease Research, Perelman School of Medicine at the University of Pennsylvania, Philadelphia, USA
}

\footnotetext{
* Corresponding author at: Department of Molecular Neuroscience, UCL, Institute of Neurology, London, UK. Tel.: +44 (0)20 76798199.
} 
${ }^{\mathrm{y}}$ Banner Sun Health Research Institute, Sun City, AZ, USA

${ }^{\mathrm{z}}$ Inserm U1127, CNRS UMR7225, Sorbonne Universites, Institut du Cerveau et de la Moelle epiniere, Paris, France

${ }^{\text {aa }}$ Department of Neurosciences, University of California, San Diego, La Jolla, CA, USA; Veterans Affairs San Diego Healthcare System, La Jolla, CA, USA

${ }^{\mathrm{bb}}$ Department of Neurosciences, University of California, San Diego, La Jolla, CA, USA; Department of Pathology, University of California, San Diego,

La Jolla, CA, USA

${ }^{\mathrm{cc}}$ Neurology Service, University of Coimbra Hospital, Coimbra, Portugal

${ }^{\mathrm{dd}}$ Memory Unit, Department of Neurology, University Hospital Mutua de Terrassa, University of Barcelona, and Fundacio de Docencia I Recerca

Mutua de Terrassa, Terrassa, Barcelona, Spain. Centro de Investigacion Biomedica en Red Enfermedades Neurdegenerativas (CIBERNED), Madrid, Spain

${ }^{\mathrm{ee}}$ Molecular Neurology, Research Programs Unit, University of Helsinki, Department of Neurology, Helsinki University Hospital, Helsinki, Finland

${ }^{\mathrm{ff}}$ Department of Pathology, University of Helsinki and Helsinki University Hospital, Helsinki, Finland

${ }^{g g}$ Department of Neuropathology and Neurosurgery, Helsinki University Hospital and University of Helsinki, Helsinki, Finland

hh Neurology Department, Mayo Clinic, Rochester, MN, USA

ii Department of Psychiatry and Department of Psychology, Mayo Clinic, Jacksonville, FL, USA

${ }^{\mathrm{ij}}$ MRC Centre for Neuropsychiatric Genetics and Genomics, School of Medicine, Cardiff University, Cardiff, UK

${ }^{\mathrm{kk}}$ Department of Neurology, Mayo Clinic, Jacksonville, FL, USA

${ }^{11}$ Knight Alzheimers Disease Research Center, Department of Neurology, Washington University School of Medicine, Saint Louis, MO, USA

$\mathrm{mm}$ Institute of Brain, Behaviour and Mental Health, Faculty of Medical and Human Sciences, University of Manchester, Manchester, UK

${ }^{\mathrm{nn}}$ Brain and Mind Centre, Sydney Medical School, The University of Sydney, Sydney, Australia

${ }^{\circ}$ Genetics and Pharmacogenomics, Merck and Co, West Point, PA, USA

${ }^{\mathrm{pp}}$ Department of Medical Sciences and Institute of Biomedicine, iBiMED, University of Aveiro, Aveiro, Portugal

\section{A R T I C L E I N F O}

Article history:

Received 21 June 2018

Received in revised form 15 October 2018

Accepted 15 October 2018

Available online 24 October 2018

Keywords:

Dementia with Lewy bodies

Copy number variants

MAPT

SNCA

Genome-wide

\begin{abstract}
A B S T R A C T
The role of genetic variability in dementia with Lewy bodies (DLB) is now indisputable; however, data regarding copy number variation (CNV) in this disease has been lacking. Here, we used whole-genome genotyping of 1454 DLB cases and 1525 controls to assess copy number variability. We used 2 algorithms to confidently detect CNVs, performed a case-control association analysis, screened for candidate CNVs previously associated with DLB-related diseases, and performed a candidate gene approach to fully explore the data. We identified $5 \mathrm{CNV}$ regions with a significant genome-wide association to DLB; 2 of these were only present in cases and absent from publicly available databases: one of the regions overlapped $L A P T M 4 B$, a known lysosomal protein, whereas the other overlapped the NME1 locus and SPAG9. We also identified DLB cases presenting rare CNVs in genes previously associated with DLB or related neurodegenerative diseases, such as SNCA, APP, and MAPT. To our knowledge, this is the first study reporting genome-wide CNVs in a large DLB cohort. These results provide preliminary evidence for the contribution of CNVs in DLB risk.
\end{abstract}

(c) 2019 Elsevier Inc. All rights reserved.

\section{Introduction}

Dementia with Lewy bodies (DLB) is a common and complex form of neurodegenerative disease, and its diagnosis can often be complicated by phenotypic similarities with Alzheimer's disease (AD), Parkinson's disease (PD), or even frontotemporal dementia (FTD) (Claassen et al., 2008; Heidebrink, 2002). A more accurate DLB diagnosis is usually obtained by integrating clinical and pathological data from brain autopsy (McKeith et al., 2017).

Genetic studies in DLB have been limited, certainly in comparison with studies on $\mathrm{AD}$ or $\mathrm{PD}$, for a number of reasons, most notably because DLB has not been historically considered a genetic disease, given the lack of multiplex kindreds where the disease segregates. In addition, large cohorts of patients are difficult to collect given the frequency of the disease and the rate of misdiagnosis. Despite this, recent studies have conclusively shown that there is a role for genetics in the etiology of DLB (Bras et al., 2014; Guerreiro et al., 2018, 2016; Nalls et al., 2013; Peuralinna et al., 2015). Exome sequencing studies have been performed in small cohorts, as have case studies and Sanger sequencing of specific target genes (Clark et al., 2009; Geiger et al., 2016; Keogh et al., 2016; Koide et al., 2002; Ohtake et al., 2004). Copy number variation (CNV) has not been assessed thus far in DLB, particularly in an unbiased manner and at a genome-wide level.

CNVs have been widely studied in a number of neurological conditions, particularly in developmental phenotypes such as schizophrenia and autism (Glessner et al., 2009; Marshall et al., 2017; McCarthy et al., 2009) where several microdeletions and microduplications (100-600 kb) have been found to be associated with both diseases (Bassett et al., 2017; Cook et al., 1997; McCarthy et al., 2009; Stefansson et al., 2008; Weiss et al., 2008). In these phenotypes, CNVs play a prominent role in the disease genetic architecture.

Several studies have analyzed CNVs in AD, where APP duplications have been unequivocally shown to cause disease (Delabar et al., 1987; Ghani et al., 2012; Swaminathan et al., 2011, 2012; Zheng et al., 2014, 2015). In PD, pathogenic CNVs are also known to occur in SNCA, PARK2, PINK1, and PARK7 (Bonifati et al., 2003; Chartier-Harlin et al., 2004; Ibáñez et al., 2004; Lesage et al., 2008; Marongiu et al., 2007; Waters and Miller, 1994). Together, these data show that CNVs are an important mutational event in neurological conditions.

Here, we report the first genome-wide analysis of CNVs in DLB in a large cohort of patients, many of which with neuropathology diagnoses of DLB. We performed a case-control association study that was complemented by discovery stage analyses guided by candidate genes and CNVs previously reported as being associated with DLB-related neurodegenerative diseases.

\section{Materials and methods}

\subsection{Sample selection}

A total of 1454 patients diagnosed with DLB and of European ancestry were selected for this study. Diagnosis of DLB was made according to clinical or pathological criteria (McKeith et al., 2005). Briefly, these included 298 clinically diagnosed and 1156 neuropathologically diagnosed cases. Detailed sample and processing 
information has been described previously (Guerreiro et al., 2018). Data from 1525 control samples were obtained from The Genetic Architecture of Smoking and Smoking Cessation study (phs000404.v1.p1) publicly available at the database of genotypes and phenotypes (https://www.ncbi.nlm.nih.gov/projects/gap/cgibin/study.cgi?study_id=phs000404.v1.p1). Supplementary Fig. 1 shows an overview of the study design, different quality control (QC) steps, and analyses performed.

\subsection{Genotyping, quality control, and CNV calling}

Seven hundred fifty-four DLB samples were genotyped on HumanOmni2.5Exome-8 v1.0.B Illumina arrays, and 700 DLB samples were genotyped using Infinium OmniExpress-24 v1.2.A1 Illumina arrays (Illumina, Inc, CA, USA). Control samples were genotyped on HumanOmni2.5-4 v1.D arrays (Illumina, Inc, CA, USA). Intensity files were analyzed using GenomeStudio v2011.1 software (Illumina, Inc, CA, USA) along with the respective manufacturer's cluster files. QC procedures were performed in GenomeStudio (GS) before CNV analysis as described by Jarick et al. (Jarick et al., 2014). In short, samples with call rates lower than 0.97 were filtered out. SNP statistics were recalculated following visual inspection of B allele frequency (BAF) and $\log \mathrm{R}$ ratio (LRR) plots. SNPs with GenTrain scores below 0.7 were excluded. Finally, samples with substantial cryptic relatedness scores (PI_HAT > 0.1) were removed, as previously described (Guerreiro et al., 2018).

CNV calls were generated using 2 different algorithms: cnvPartition v2.3.0 (Illumina, Inc) and PennCNV v1.0.4 (Wang et al., 2007). CNV calling based on cnvPartition was performed by GS with default parameters. For PennCNV, probe positions, LRR, and BAF values for samples that passed $\mathrm{QC}$ procedures were exported from GS. Population frequency of the B allele (PFB) files was calculated for each array separately. All smoking cessation samples were used to generate CNVs in cnvPartition and PennCNV, but only a subset of the best performing 700 samples was used for the compilation of the PFB file in PennCNV to match the number of samples used for cases. PennCNV GC-model files were then created based on these PFBs. Finally, CNVs were inferred by PennCNV using the hidden Markov model and the GC-model for wave adjustment. Calls for the $\mathrm{X}$ chromosome were generated separately. Chromosome Y SNPs were not analyzed.

\subsection{CNV quality control and analysis}

To improve the quality of CNVs, only calls generated by both algorithms were kept, whereas calls made by a single algorithm or calls of opposing type (e.g., assigned as a deletion by one algorithm and as duplication by the other) were discarded. Adjacent CNVs were merged if the length of the sequence between them was smaller than $50 \%$ of the length of the larger CNV (Mok et al., 2016). CNVs were excluded if they were overlapping telomeres, centromeres, known segmental duplications, the immunoglobulin, or T cell receptor loci. Samples having LRR SD $>0.28$, BAF drift $>0.002$, waviness factor $>0.04$, or having more CNV calls than $3 *$ SD + median were excluded (Marshall et al., 2017; Need et al., 2009).

To identify potentially pathogenic CNVs, we analyzed CNVs spanning known genes. We used the database of genomic variants (DGV) (http://dgv.tcag.ca/dgv/app/home, accessed November 2017) to determine the population frequency of CNVs (MacDonald et al., 2014). This information was complemented with the frequency from clinical samples available in DECIPHER v9.18 (https://decipher. sanger.ac.uk/, accessed November 2017).

\subsection{Case-control association analysis}

Case-control association analysis was implemented using ParseCNV (Glessner et al., 2013). Standard ParseCNV quality metrics were used to filter out low-quality results. CNVs that were genomewide significant [ $p$-value $<5 \times 10^{-4}$ as suggested by (Glessner et al., 2013)] had a minimum length of $50 \mathrm{~kb}$, and passed visual inspection in GS were selected for further analyses.

\subsection{Candidate CNVs approach}

CNVs previously described in AD (Ghani et al., 2012; Heinzen et al., 2010; Swaminathan et al., 2011, 2012; Zheng et al., 2014, 2015), PD (Bademci et al., 2010; Liu et al., 2013; Mok et al., 2016; Pankratz et al., 2011), and FTD (Gijselinck et al., 2008) were specifically investigated in these data (Supplementary Table 1). This analysis was performed on the complete set of $\mathrm{CNV}$ results after $\mathrm{QC}$, disregarding the filters used for the case-control association analysis performed by ParseCNV.

\subsection{Candidate genes approach}

CNVs located in known AD, PD, FTD, and DLB genes were also assessed (Brás et al., 2015; Guerreiro et al., 2013, 2015, 2018; Jansen et al., 2015; Keogh et al., 2016; Koide et al., 2002; Ohtake et al., 2004; Saitoh et al., 1995). Supplementary Table 2 lists all genes studied using this approach.

\section{Results}

\subsection{CNV calling and QC steps}

After QC steps at the GS level, a total of 2819 samples (1294 cases and 1525 controls) remained for further analyses. From the 754 DLB samples genotyped with HumanOmni2.5 arrays, 616 (81.7\%) samples were kept and from the $2,567,845$ probes in this array, 2,496,600 (97.2\%) passed QC. Six hundred seventy-eight (96.9\%) samples of the 700 samples genotyped with OmniExpress arrays passed QC and from the 713,599 probes available in this chip, 698,680 (97.9\%) probes remained. All controls from the Smoking Cessation database had good quality genotypes (call rate $>0.97$ ) and, consequently, no samples were excluded, and 2,390,384 (97.8\%) of the 2,443,177 probes were kept.

After combining the results obtained by the 2 CNV calling algorithms (cnvPartition and PennCNV), excluding samples because of their relatedness, and performing the PennCNV QC steps on the LRR and BAF values and number of calls, a final number of 2615 individuals (1187 DLB cases and 1428 control samples) and 80,416 CNVs were analyzed. All samples carrying CNVs were confirmed to be of European/North American ancestry by merging their data with that of 1000 Genomes.

\subsection{Case-control association analysis}

Of the $494 \mathrm{CNV}$ regions resulting from the ParseCNV analysis, only 5 passed QC checks and were statistically significant (Table 1). Of these, 2 of the regions were not present in our control population or in public databases: the deletion overlapping LAPTM4B ( $p=$ $\left.6.29 \times 10^{-7}\right)$ and the one overlapping SPAG9-NME1-NME2 $(p=$ $\left.2.72 \times 10^{-4}\right)$ (Fig. 1).

\subsection{Candidate CNVs approach}

Five CNVs previously associated with DLB-related neurodegenerative diseases were found in DLB patients (Table 1). Two of these 
Table 1

Results from the three types of analyses

\begin{tabular}{|c|c|c|c|c|c|c|c|c|c|}
\hline Genes & Location & CNV & $p$-value & $\begin{array}{l}\text { Cases } \\
\left(\text { Neuro }^{\mathrm{a}}\right)\end{array}$ & Controls & $\begin{array}{l}\text { Cases } \\
\text { frequency }\end{array}$ & $\begin{array}{l}\text { Controls } \\
\text { frequency }\end{array}$ & $\begin{array}{l}\text { DGV } \\
\text { frequency }\end{array}$ & $\begin{array}{l}\text { DECIPHER } \\
\text { frequency }\end{array}$ \\
\hline \multicolumn{10}{|l|}{ Case-control association analysis } \\
\hline ADGRG7,TFG & chr3:100,357,671-100,439,759 & Gain & $8.93 \times 10^{-5}$ & $21(18)$ & 13 & $1.77 \times 10^{-2}$ & $9.10 \times 10^{-3}$ & $1.43 \times 10^{-2}$ & $2.09 \times 10^{-2}$ \\
\hline PDZD2 & chr5:32101,400-32,106,628 & Gain & $2.94 \times 10^{-6}$ & $14(12)$ & 0 & $1.18 \times 10^{-2}$ & 0 & $3.00 \times 10^{-4}$ & $1.69 \times 10^{-4}$ \\
\hline LAPTM $4 B$ & chr8:98755,434-98,800,334 & Loss & $6.29 \times 10^{-7}$ & $12(6)$ & 0 & $1.01 \times 10^{-2}$ & 0 & 0 & 0 \\
\hline MSR1 & chr8:15948,235-16,021,468 & Loss & $1.20 \times 10^{-4}$ & $13(7)$ & 4 & $1.10 \times 10^{-2}$ & $2.80 \times 10^{-3}$ & $4.30 \times 10^{-3}$ & $7.10 \times 10^{-3}$ \\
\hline NME1,NME1-NME2,SPAG9 & chr17:49,177,096-49,231,786 & Loss & $2.72 \times 10^{-4}$ & $9(4)$ & 0 & $7.58 \times 10^{-3}$ & 0 & 0 & 0 \\
\hline \multicolumn{10}{|l|}{ Candidate CNVs approach } \\
\hline CSMD1 & chr8:4,033,908-4,126,540 & Loss & $2.89 \times 10^{-2 b}$ & $3(2)$ & 0 & $2.53 \times 10^{-3}$ & 0 & $3.00 \times 10^{-4}$ & 0 \\
\hline DDX11,OVOS2 & $\operatorname{chr} 12: 31,249,834-31,407,303$ & Gain & $1.41 \times 10^{-2 b}$ & $4(2)$ & 0 & $3.37 \times 10^{-3}$ & 0 & $4.61 \times 10^{-2}$ & 0 \\
\hline $\begin{array}{l}\text { CYFIP1,GOLGABI,NIPA1, } \\
\text { NIPA2,TUBGCP5,WHAMML1 }\end{array}$ & chr15:22,750,305-23,272,733 & Gain & na & $5(5)$ & 8 & $4.21 \times 10^{-3}$ & $5.60 \times 10^{-3}$ & $2.50 \times 10^{-3}$ & $1.86 \times 10^{-3}$ \\
\hline CHRNAT.OTUDTA & $\operatorname{chr} 15: 31,932,865-32,515,849$ & Loss or Gain & na & $6(5)$ & 13 & $5.05 \times 10^{-3}$ & $9.10 \times 10^{-3}$ & $6.90 \times 10^{-3}$ & $8.79 \times 10^{-3}$ \\
\hline $\begin{array}{l}\text { ASPHD1,BOLA2,C16orf54,CDIPT,CDIPT-AS1, } \\
\text { KIF22,MAZ,MVP,PAGR1,PRRT2,QPRT,SEZ6L2, } \\
\text { SPN,ZG16 }\end{array}$ & chr16:29,595,483-29,912,902 & Gain & na & $1(1)$ & 0 & $8.42 \times 10^{-4}$ & 0 & 0 & $1.69 \times 10^{-4}$ \\
\hline \multicolumn{10}{|l|}{$\begin{array}{l}S P N, \angle G 16 \\
\text { Candidate genes approach }\end{array}$} \\
\hline DNAJC6,LEPR,LEPROT & $\operatorname{chr} 1: 65,854,556-65,955,725$ & Gain & na & $1(0)$ & 1 & $8.42 \times 10^{-4}$ & $7.00 \times 10^{-4}$ & $1.72 \times 10^{-4}$ & $2.53 \times 10^{-3}$ \\
\hline SNCA,SNCA-AS1,GPRIN3,MMRN1,CCSER1 & chr4:90,035,549-91,420,358 & Gain & na & $1(1)$ & 0 & $8.42 \times 10^{-4}$ & 0 & $6.42 \times 10^{-4}$ & 0 \\
\hline PARK2 & chr6:161,601,162-163,259,260 & Loss or Gain & na & $13(8)$ & 28 & $1.10 \times 10^{-2}$ & $1.96 \times 10^{-2}$ & $2.30 \times 10^{-3}$ & $1.69 \times 10^{-1}$ \\
\hline GABRB3,GABRA5,GABRG3 & $\operatorname{chr} 15: 26,996,126-27,220,713$ & Gain & na & $1(1)$ & 0 & $8.42 \times 10^{-4}$ & 0 & 0 & $1.18 \times 10^{-3}$ \\
\hline $\begin{array}{l}\text { MAPT,CRHR1,KANSL1,KANSL1-AS1, } \\
\text { MAPT-AS1,MAPT-IT1,SPPL2C,STH }\end{array}$ & chr17:43,661,362-44,345,063 & Gain & na & $2(0)$ & 0 & $1.68 \times 10^{-3}$ & 0 & $1.03 \times 10^{-4}$ & $1.18 \times 10^{-3}$ \\
\hline $\begin{array}{l}\text { APP,ADAMTS1,ADAMTS5,ATP5J,CYYR1, } \\
\text { CYYR1-AS1,GABPA,JAM2,MRPL39 }\end{array}$ & $\operatorname{chr} 21: 25,063,840-28,522,487$ & Gain & na & $1(0)$ & 0 & $8.42 \times 10^{-4}$ & 0 & 0 & 0 \\
\hline $\begin{array}{l}\text { CHCHD10,ADORA2A,ADORA2A-AS1, } \\
\text { C22orf15,CABIN1,CES5AP1,DDT,DDTL, } \\
\text { DERL3,DRICH1,GGT1,GGT5,GSTT1,GSTT1-AS1, } \\
\text { GSTT2,GSTT2B,GSTTP1,GSTTP2,GUCD1, } \\
\text { GUSBP11,IGLL1,LRRC75B,MIF,MIF-AS1, } \\
\text { MMP11,POM121L9P, RGL4,SLC2A11,SMARCB1, } \\
\text { SNRPD3,SPECC1L,SUSD2,UPB1,VPREB3, } \\
\text { ZDHHC8P1,ZNF70 }\end{array}$ & chr22:23,690,325-25,011,417 & Gain & na & $1(1)$ & 0 & $8.42 \times 10^{-4}$ & 0 & $6.00 \times 10^{-4}$ & $1.18 \times 10^{-3}$ \\
\hline CYP2D6,NDUFA6-AS1 & $\operatorname{chr} 22: 42,522,613-42,531,210$ & Loss or Gain & na & $1(1)$ & 4 & $8.42 \times 10^{-4}$ & $2.80 \times 10^{-3}$ & $2.20 \times 10^{-1}$ & $3.00 \times 10^{-2}$ \\
\hline
\end{tabular}

All genomic coordinates are for the genome assembly hg19.

a Neuropathological diagnosis; na-not applicable; $p$-value-these were calculated including all cases (not only neuropathologically confirmed cases).

${ }^{\mathrm{b}} p$-values resulting from the case-control association analysis. 
were present in the control group with a higher frequency than in the patient group, and the remaining 3 are described in public databases and are detailed next. The duplication identified on chromosome 12 overlapping DDX11 and OVOS2 has a frequency 10fold higher in DGV than in the DLB cohort. The 16p11.2 microduplication found in one DLB patient has a frequency of $1.69 \times 10^{-4}$ in the DECIPHER database but does not occur in any control samples or in the DGV database. One of the CNVs that was previously significantly associated with $\mathrm{AD}$ locates at chr8:2,792,8744,852,328 and overlaps CSMD1 (Swaminathan et al., 2011). CSMD1 has frequent deletions and duplications spanning the whole gene as reported in DGV. Our results agree with this: at this locus, we identified over 100 deletions in cases and controls. One region in the gene has a deletion in 3 cases and in no controls and this CNV showed a suggestive significance in our DLB case-control association analysis. Therefore, we only report this shorter region in Table 1.

\subsection{Candidate genes approach}

We investigated CNVs in genes known to be associated with diseases that are related to DLB (Supplementary Table 2) and identified a total of $8 \mathrm{CNVs}$ (Table 1 ). These included one duplication in APP occurring in a clinically diagnosed case. This large duplication is not present in the databases or in the control cohort. Two DLB subjects were found to carry duplications spanning MAPT, and one neuropathologically diagnosed patient was found to carry a SNCA duplication (Fig. 2). PARK2 was found to have many copy number losses and gains in controls $(n=28)$ and cases $(n=13)$ but none were homozygous. A duplication including $C H C H D 10$ was also identified in a neuropathologically diagnosed DLB patient. No CNVs were identified in $G B A$, the gene presenting the strongest association with DLB.

\section{Discussion}

We performed a systematic analysis of CNVs in a large cohort of DLB patients using 3 main approaches. The first of these approaches was a case-control association analysis, which resulted in 5 significant CNV regions that have not been previously described as associated with the disease. The most significant result from this analysis was a deletion spanning a lysosome-associated transmembrane protein, LAPTM4B. Intraneuronal alpha-synuclein clearance likely occurs through a variety of mechanisms to maintain protein homeostasis. However, recent data have highlighted the importance of lysosomal pathways for degradation of this protein (Webb et al., 2003). Interestingly, a member of the same protein family, LAPTM5, was one of the top hits for incidental DLB in a recent network analysis study (Santpere et al., 2018). Although we cannot directly link this CNV to the development of DLB in these cases, it is interesting that a lysosomal enzyme is the top hit in our association analysis, given the prominent role of the lysosome in Lewy body diseases. In fact, a strong GWAS hit for DLB is GBA, a gene involved in lysosomal lipid storage disorders.

Also associated with DLB and absent from publicly available databases was a deletion overlapping the NME1 locus. NME1 is involved in purine metabolism, which has been reported to be disrupted in AD, PD, and Creutzfeldt-Jakob disease. NME1 mRNA was also found to be reduced in these diseases (Ansoleaga et al., 2015, 2016; GarciaEsparcia et al., 2015). Here, we identified a deletion at the $3^{\prime}$-end of NME1, which could be consistent with a reduced expression of the gene in DLB, although this was not tested in the present study.

Using a candidate gene approach where we analyzed genes known to have a role in DLB and DLB-related diseases, we identified several CNVs of potential interest. The hallmark of DLB at autopsy is the accumulation of alpha-synuclein protein within neurons and their processes, termed Lewy bodies and Lewy neurites (Spillantini et al., 1997). Variants in the SNCA gene, which encodes alphasynuclein, have been previously associated with the risk of developing DLB (Bras et al., 2014; Guerreiro et al., 2018). In addition to point mutations, CNVs including SNCA are known to cause PD, and over the past years, evidence has suggested that this gene may also be duplicated in DLB. Nishioka et al. identified a PD family with a duplication spanning all of SNCA and MMRN1 where the proband was later neuropathologically diagnosed as DLB (Nishioka et al., 2006; Obi et al., 2008). Four neuropathologically diagnosed DLB cases presented a large duplication from DSPP to PDLIM5 including $S N C A, 3$ of these were heterozygous and 1 was homozygous (Ikeuchi et al., 2008). A duplication in SNCA was also described in a probable DLB patient in a study with 99 cases (Meeus et al., 2012). Here, we add to this body of evidence, by identifying another patient neuropathologically diagnosed with DLB carrying a SNCA duplication. In our DLB cohort, this duplication shows a similar frequency to that provided by DGV. However, the frequency reported in DGV results from 2 entries in that database. When looking in more detail at these 2 entries, they are actually duplicated entries from the same Human Genome Diversity Project (HGDP) sample from Cambodia (HGDP00721). Given that information for each HGDP samples is limited to sex of the individual, population, and geographic origin, it is possible this sample originated from a PD or DLB patient or from an asymptomatic carrier, as these have previously been reported, with SNCA multiplications having particularly low penetrance levels in Asian populations (Ahn et al., 2008; Nishioka et al., 2006). It is also possible the duplication reported is an artifact caused by the creation or passage of the lymphoblast cell lines used to extract DNA (Simon-Sanchez et al., 2007).
A
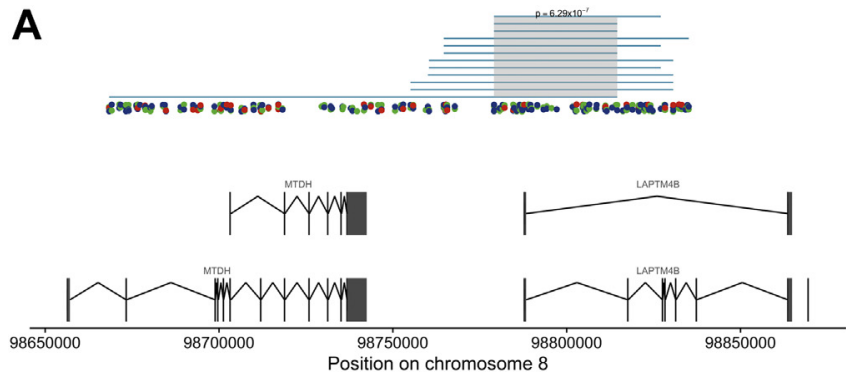

B

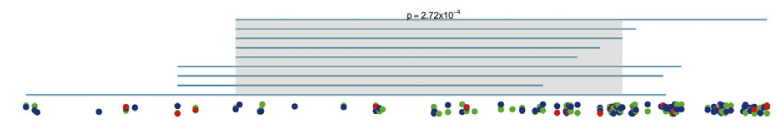

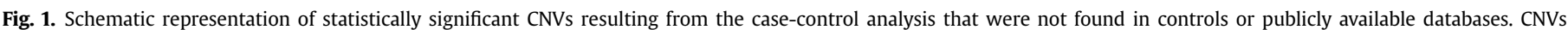

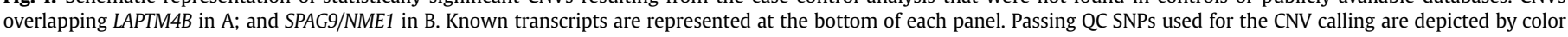

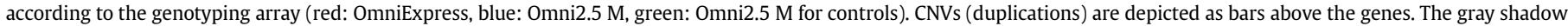

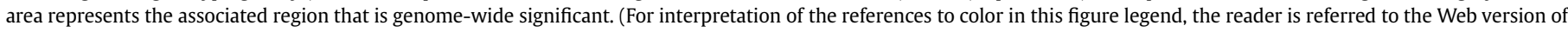
this article.) 


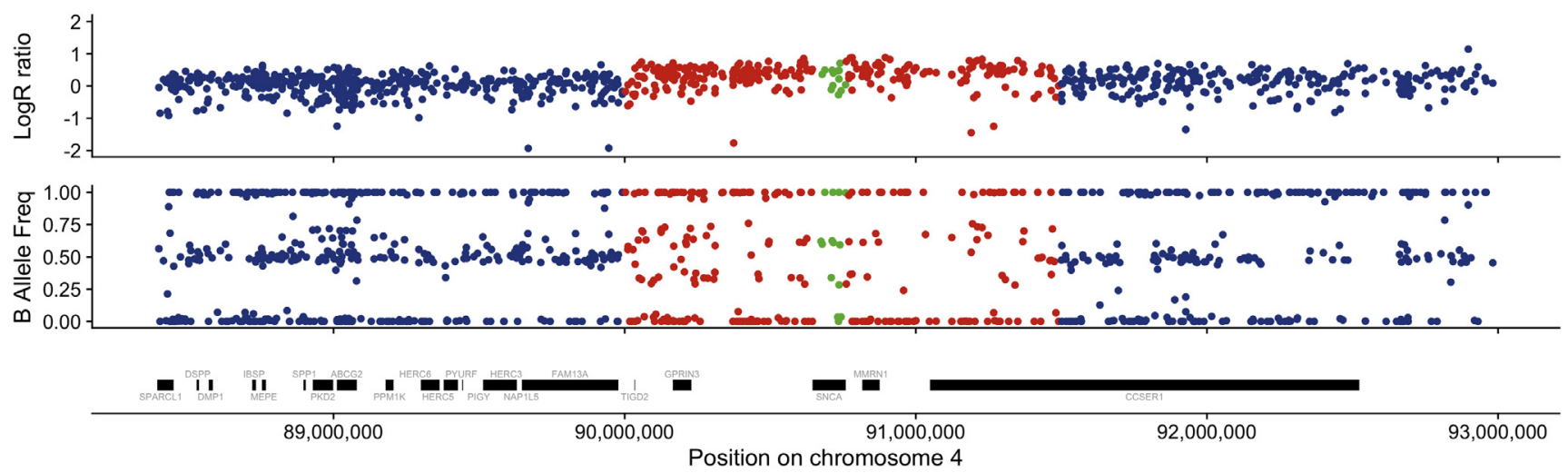

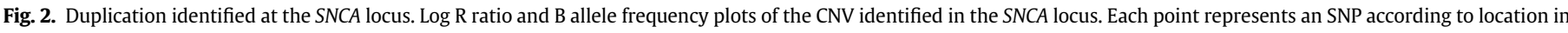

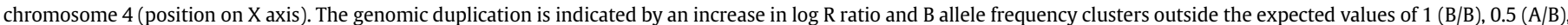

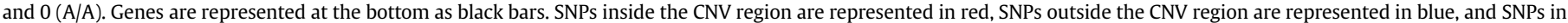
SNCA are represented in green. (For interpretation of the references to color in this figure legend, the reader is referred to the Web version of this article.)

We also identified one heterozygous duplication encompassing CHCHD10, a gene previously shown to cause FTD and/or amyotrophic lateral sclerosis (Zhang et al., 2015). However, given that disease-associated CHCHD10 mutations are loss-of-function (Perrone et al., 2017), it is not clear whether a duplication of the gene would be pathogenic.

GABRB3 is a gamma-aminobutyric acid (GABA) receptor that was reported to be associated with DLB in a recent GWAS but did not survive independent replication (Guerreiro et al., 2018). However, loss of GABA receptors could underlie the typical visual hallucinations in DLB (Khundakar et al., 2016), and because of this, we specifically looked at CNVs in GABRB3 and identified a duplication in one case. Given the GWAS results previously mentioned, the CNV detected here and the fact that GABA receptor neurotransmission is altered in DLB (Santpere et al., 2018), it is tempting to speculate that genetic variability in GABA receptors may, in fact, modulate risk for DLB.

We identified 2 clinically diagnosed DLB samples with MAPT duplications (Fig. 3). MAPT was not found to be significantly associated with DLB in recent GWAS (Bras et al., 2014; Guerreiro et al., 2018), but the MAPT H1 haplotype was previously described as a possible risk factor for DLB (Cervera-Carles et al., 2016; Labbé et al., 2016) and is a well-known genetic risk factor for PD. Previous studies of small cohorts of FTD patients have not revealed causative MAPT duplications (Lladó et al., 2007; Skoglund et al., 2009) but the screening of French FTD patients including multiplex families led to the identification of a heterozygous partial deletion of MAPT (Rovelet-Lecrux et al., 2009) and a 17q21.31 microduplication in an atypical FTD case (Rovelet-Lecrux et al., 2010). More recently, MAPT duplications were shown to increase expression of MAPT mRNA and were found to cause tangle pathology without $A \beta$ deposition in probable AD patients (Le Guennec et al., 2017).

PARK2 homozygous CNVs are the most common copy number cause of $\mathrm{PD}$, accounting for more than $50 \%$ of all pathogenic mutations in the gene and more frequently affecting the region between exons 2 and 7 (Hedrich et al., 2004; Kim et al., 2012). Our results showed no significant differences in the frequency of heterozygous CNVs overlapping PARK2 between DLB cases and controls, similar to the findings by Kay et al. in PD (Kay et al., 2010). In addition, we did not find any homozygous PARK2 CNVs suggesting that CNVs in this gene do not play a causative role in DLB.

APP duplications are known to cause AD (Delabar et al., 1987; Ghani et al., 2012; Swaminathan et al., 2011, 2012; Zheng et al., 2014, 2015). The sample carrying an APP duplication in our cohort has a clinical diagnosis of DLB without neuropathological confirmation; it is therefore possible that this is an AD case misdiagnosed as DLB. However, there have been reports in the literature of DLB cases associated with APP duplications. For example, in a French family presenting with a diverse phenotype, APP duplication was associated with DLB confirmed by neuropathological findings (Guyant-Marechal et al., 2008). Similarly, one case with Lewy body-variant $\mathrm{AD}$ was reported in a multigenerational dementia family from the Netherlands (Sleegers et al., 2006). DLB cases frequently present $A \beta$ pathology at autopsy (Hepp et al., 2016), and it has been suggested that $A \beta$ accumulation can trigger Lewy body disease (Masliah et al., 2001).

There are 2 main limitations in this study: first, this is a relatively small-sized cohort, which means we cannot confidently assess associations of CNVs with low effect sizes on disease; second, we did not perform independent replication of these findings, which precludes us from establishing definite associations or causes of disease. Despite these limitations, we report on the first systematic analysis of CNVs in a large cohort of DLB patients, using wellestablished analytical practices. We identified potential disease causing CNVs as well as potential novel candidate genes for DLB. Despite this, our results suggest that it is unlikely that CNVs play a significant role in the pathogenesis of DLB.

\section{Disclosure}

The authors have no actual or potential conflicts of interest.

\section{Acknowledgements}

RG and JB work is funded by fellowships from the Alzheimer's Society. TO work is funded by a scholarship from The Lewy Body Society. For the neuropathologically confirmed samples from Australia, tissues were received from the Sydney Brain Bank, which is supported by Neuroscience Research Australia and the University of New South Wales, and GMH is funded by an NHMRC senior principal research fellowship. The authors thank the South West Dementia Brain Bank (SWDBB) for providing brain tissue for this study. The SWDBB is supported by BRACE (Bristol Research into Alzheimer's and Care of the Elderly), Brains for Dementia Research, and the Medical Research Council. The authors acknowledge the Oxford Brain Bank, supported by the Medical Research Council (MRC), Brains for Dementia Research (BDR) (Alzheimer Society and Alzheimer Research UK), Autistica UK, and the NIHR Oxford Biomedical Research Center. The brain samples 

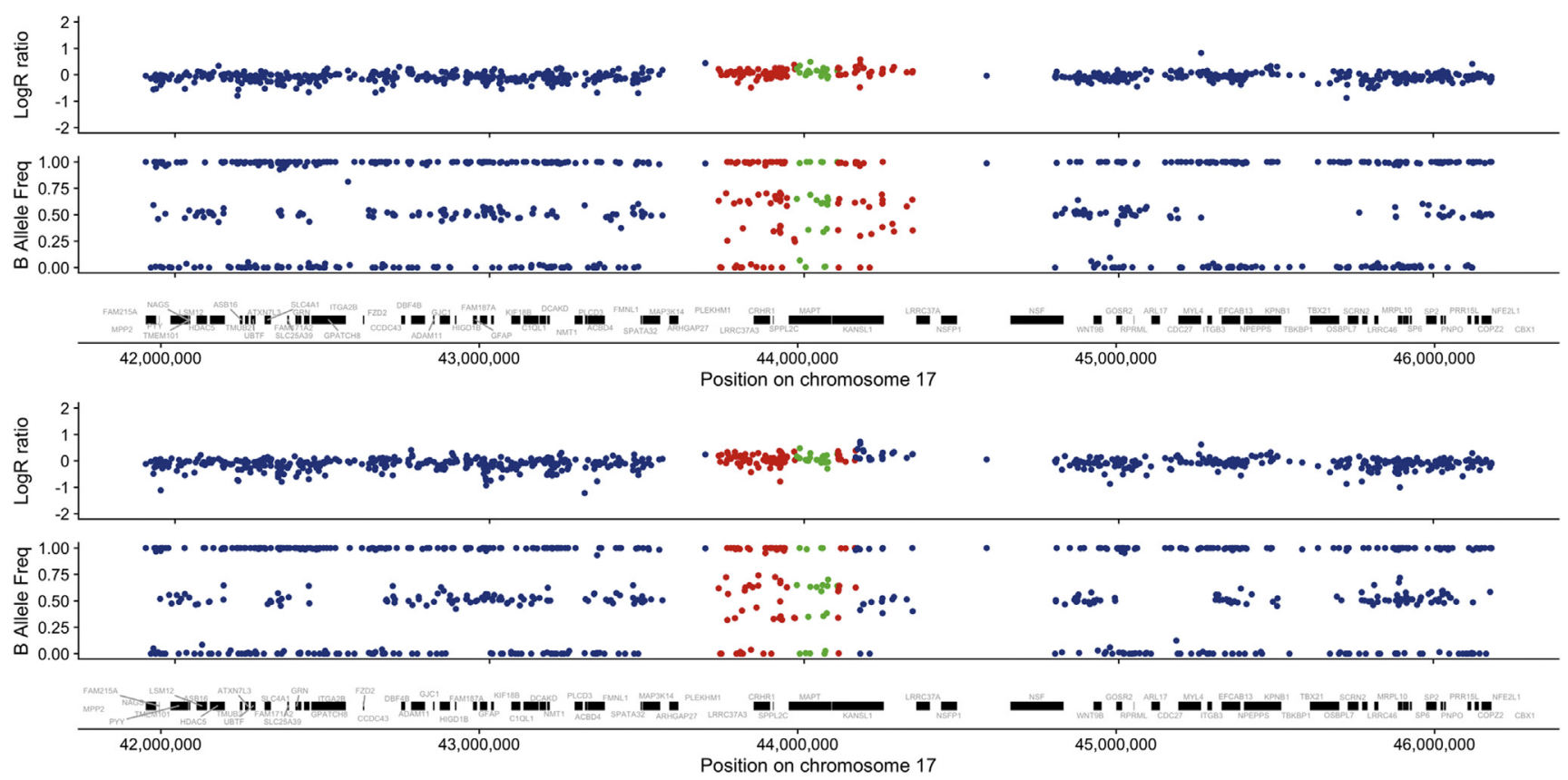

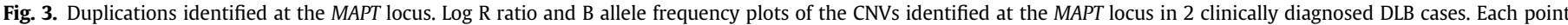

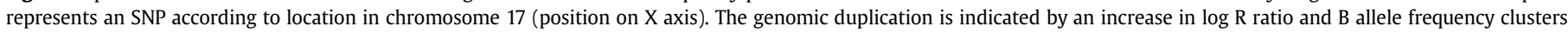

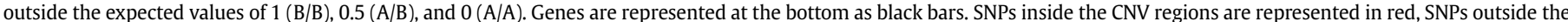

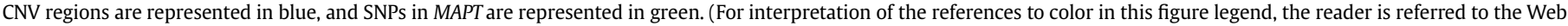
version of this article.)

and/or bio samples were obtained from The Netherlands Brain Bank, Netherlands Institute for Neuroscience, Amsterdam (open access: www.brainbank.nl). All materials have been collected from donors for or from whom a written informed consent for a brain autopsy, and the use of the material and clinical information for research purposes had been obtained by the NBB. This study was also partially funded by the Wellcome Trust, and the Canadian Consortium on Neurodegeneration and Aging of the Canadian Institutes of Health Research (PSGH). Work from YC was supported by the CERCA Program/Generalitat de Catalunya, Barcelona, Catalonia, Spain. The Nottingham Genetics Group is supported by ARUK and The Big Lottery Fund. The effort from Columbia University was supported by the Taub Institute, the Panasci Fund, the Parkinson's Disease Foundation, and NIH grants NS060113 (LC), P50AG008702 (P.I. Scott Small), P50NS038370 (P.I.R. Burke), and UL1TR000040 (P.I.H. Ginsberg). OAR is supported by the Michael J. Fox Foundation for Parkinson's Research, NINDS R01\# NS078086. The Mayo Clinic Jacksonville is a Morris K. Udall Parkinson's Disease Research Center of Excellence (NINDS P50 \#NS072187) and is supported by The Little Family Foundation and by the Mangurian Foundation Program for Lewy Body Dementia research and the Alzheimer Disease Research Center (P50 AG016547). The work from the Mayo Clinic Rochester is supported by the National Institute on Aging (P50 AG016574 and U01 AG006786). This work has received support from The Queen Square Brain Bank at the UCL Institute of Neurology, where TL is funded by an ARUK senior fellowship. Some of the tissue samples studied were provided by the MRC London Neurodegenerative Diseases Brain Bank and the Brains for Dementia Research project (funded by Alzheimer's Society and ARUK). This research was supported in part by both the NIHR UCLH Biomedical Research Center and the Queen Square Dementia Biomedical Research Unit. This work was supported in part by the Intramural Research Program of the National Institute on Aging, National Institutes of Health, Department of Health and Human Services; project AG000951-12. The University of
Pennsylvania case collection is funded by the Penn Alzheimer's Disease Core Center (AG10124) and the Penn Morris K. Udall Parkinson's Disease Research Center (NS053488). Tissue samples from UCSD are supported by NIH grant AG05131. The authors thank the brain bank GIE NeuroCEB, the French program "Investissements d'avenir" (ANR-10-IAIHU-06). PJT and LM are supported by the Helsinki University Central Hospital and Sigrid Juselius Foundation and the Finnish Academy. This work was in part supported by the Canadian Consortium on Neurodegeneration in Aging (ER). The authors acknowledge the contribution of data from Genetic Architecture of Smoking and Smoking Cessation accessed through dbGAP. Funding support for genotyping, which was performed at the Center for Inherited Disease Research (CIDR), was provided by 1 X01 HG005274-01. CIDR is fully funded through a federal contract from the National Institutes of Health to The Johns Hopkins University, contract number HHSN268200782096C. Assistance with genotype cleaning, as well as with general study coordination, was provided by the Gene Environment Association Studies (GENEVA) Coordinating Center (U01 HG004446). Funding support for collection of data sets and samples was provided by the Collaborative Genetic Study of Nicotine Dependence (COGEND; P01 CA089392) and the University of Wisconsin Transdisciplinary Tobacco Use Research Center (P50 DA019706, P50 CA084724). This work was supported in part by the Intramural Research Program of the National Institutes of Health (National Institute of Neurological Disorders and Stroke; project ZIA NS003154). Tissue samples for genotyping were provided by the Johns Hopkins Morris K. Udall Center of Excellence for Parkinson's Disease Research (NIH P50 NS38377) and the Johns Hopkins Alzheimer Disease Research Center (NIH P50 AG05146). This study was supported by grants from the National Institutes of Health, the Canadian Institute for Health Research, and the Krembil Foundation. Additional support was provided by the Babcock Memorial Trust and by the Barbara and Neal Henschel Charitable Foundation. 
Appendix A. Supplementary data

Supplementary data to this article can be found online at https:// doi.org/10.1016/j.neurobiolaging.2018.10.019.

\section{References}

Ahn, T.-B., Kim, S.Y., Kim, J.Y., Park, S.-S., Lee, D.S., Min, H.J., Kim, Y.K., Kim, S.E., Kim, J.-M., Kim, H.-J., Cho, J., Jeon, B.S., 2008. alpha-Synuclein gene duplication is present in sporadic Parkinson disease. Neurology 70, 43-49.

Ansoleaga, B., Garcia-Esparcia, P., Llorens, F., Hernández-Ortega, K., Carmona Tech, M., Antonio Del Rio, J., Zerr, I., Ferrer, I., 2016. Altered Mitochondria, protein Synthesis Machinery, and Purine Metabolism are Molecular Contributors to the Pathogenesis of Creutzfeldt-Jakob Disease. J. Neuropathol. Exp. Neurol. https://doi.org/10.1093/jnen/nlw048.

Ansoleaga, B., Jové, M., Schlüter, A., Garcia-Esparcia, P., Moreno, J., Pujol, A., Pamplona, R., Portero-Otín, M., Ferrer, I., 2015. Deregulation of purine metabolism in Alzheimer's disease. Neurobiol. Aging 36, 68-80.

Bademci, G., Edwards, T.L., Torres, A.L., Scott, W.K., Züchner, S., Martin, E.R., Vance, J.M., Wang, L., 2010. A rare novel deletion of the tyrosine hydroxylase gene in Parkinson disease. Hum. Mutat. 31, E1767-E1771.

Bassett, A.S., Lowther, C., Merico, D., Costain, G., Chow, E.W.C., van Amelsvoort, T., McDonald-McGinn, D., Gur, R.E., Swillen, A., Van den Bree, M., Murphy, K., Gothelf, D., Bearden, C.E., Eliez, S., Kates, W., Philip, N., Sashi, V., Campbell, L., Vorstman, J., Cubells, J., Repetto, G.M., Simon, T., Boot, E., Heung, T., Evers, R., Vingerhoets, C., van Duin, E., Zackai, E., Vergaelen, E., Devriendt, K., Vermeesch, J.R., Owen, M., Murphy, C., Michaelovosky, E., Kushan, L., Schneider, M., Fremont, W., Busa, T., Hooper, S., McCabe, K., Duijff, S., Isaev, K., Pellecchia, G., Wei, J., Gazzellone, M.J., Scherer, S.W., Emanuel, B.S., Guo, T., Morrow, B.E., Marshall, C.R., International 22q11.2DS Brain and Behavior Consortium, 2017. Rare genome-wide copy number variation and expression of schizophrenia in 22q11.2 deletion syndrome. Am. J. Psychiatry 174, 1054-1063.

Bonifati, V., Rizzu, P., van Baren, M.J., Schaap, O., Breedveld, G.J., Krieger, E., Dekker, M.C.J., Squitieri, F., Ibanez, P., Joosse, M., van Dongen, J.W., Vanacore, N., van Swieten, J.C., Brice, A., Meco, G., van Duijn, C.M., Oostra, B.A., Heutink, P., 2003. Mutations in the DJ-1 gene associated with autosomal recessive earlyonset parkinsonism. Science 299, 256-259.

Bras, J., Guerreiro, R., Darwent, L., Parkkinen, L., Ansorge, O., Escott-Price, V., Hernandez, D.G., Nalls, M.A., Clark, L.N., Honig, L.S., Marder, K., Van Der Flier, W.M., Lemstra, A., Scheltens, P., Rogaeva, E., St George-Hyslop, P., Londos, E., Zetterberg, H., Ortega-Cubero, S., Pastor, P., Ferman, T.J., GraffRadford, N.R., Ross, O.A. Barber, I., Braae, A., Brown, K., Morgan, K., Maetzler, W., Berg, D., Troakes, C., Al-Sarraj, S., Lashley, T., Compta, Y., Revesz, T., Lees, A., Cairns, N., Halliday, G.M., Mann, D., Pickering-Brown, S., Dickson, D.W., Singleton, A., Hardy, J., 2014. Genetic analysis implicates APOE, SNCA and suggests lysosomal dysfunction in the etiology of dementia with Lewy bodies. Hum. Mol. Genet. 23, 6139-6146.

Brás, J., Guerreiro, R., Hardy, J., 2015. SnapShot: genetics of Parkinson's disease. Cell 160, 570-570.e1.

Cervera-Carles, L., Pagonabarraga, J., Pascual-Sedano, B., Pastor, P., Campolongo, A., Fortea, J., Blesa, R., Alcolea, D., Morenas-Rodríguez, E., Sala, I., Lleó, A., Kulisevsky, J., Clarimón, J., 2016. Copy number variation analysis of the 17q21.31 region and its role in neurodegenerative diseases. Am. J. Med. Genet. B Neuropsychiatr. Genet. 171B, 175-180.

Chartier-Harlin, M.-C., Kachergus, J., Roumier, C., Mouroux, V., Douay, X., Lincoln, S., Levecque, C., Larvor, L., Andrieux, J., Hulihan, M., Waucquier, N., Defebvre, L., Amouyel, P., Farrer, M., Destée, A., 2004. Alpha-synuclein locus duplication as a cause of familial Parkinson's disease. Lancet 364, 1167-1169.

Claassen, D.O., Parisi, J.E., Giannini, C., Boeve, B.F., Dickson, D.W., Josephs, K.A., 2008. Frontotemporal dementia mimicking dementia with Lewy bodies. Cogn. Behav. Neurol. 21, 157-163.

Clark, L.N., Kartsaklis, L.A., Wolf Gilbert, R., Dorado, B., Ross, B.M., Kisselev, S., Verbitsky, M., Mejia-Santana, H., Cote, L.J., Andrews, H., Vonsattel, J.-P., Fahn, S. Mayeux, R., Honig, L.S., Marder, K., 2009. Association of glucocerebrosidase mutations with dementia with lewy bodies. Arch. Neurol. 66, 578-583.

Cook Jr., E.H., Lindgren, V., Leventhal, B.L., Courchesne, R., Lincoln, A., Shulman, C., Lord, C., Courchesne, E., 1997. Autism or atypical autism in maternally but not paternally derived proximal 15q duplication. Am. J. Hum. Genet. 60, 928-934.

Delabar, J.M., Goldgaber, D., Lamour, Y., Nicole, A., Huret, J.L., de Grouchy, J., Brown, P., Gajdusek, D.C., Sinet, P.M., 1987. Beta amyloid gene duplication in Alzheimer's disease and karyotypically normal Down syndrome. Science 235, 1390-1392.

Garcia-Esparcia, P., Hernández-Ortega, K., Ansoleaga, B., Carmona, M., Ferrer, I., 2015. Purine metabolism gene deregulation in Parkinson's disease. Neuropathol. Appl. Neurobiol. 41, 926-940.

Geiger, J.T., Ding, J., Crain, B., Pletnikova, O., Letson, C., Dawson, T.M., Rosenthal, L.S., Pantelyat, A., Gibbs, J.R., Albert, M.S., Hernandez, D.G., Hillis, A.E., Stone, D... Singleton, A.B., North American Brain Expression Consortium, Hardy, J.A., Troncoso, J.C., Scholz, S.W., 2016. Next-generation sequencing reveals substantial genetic contribution to dementia with Lewy bodies. Neurobiol. Dis. 94, 55-62.

Ghani, M., Pinto, D., Lee, J.H., Grinberg, Y., Sato, C., Moreno, D., Scherer, S.W., Mayeux, R., St George-Hyslop, P., Rogaeva, E., 2012. Genome-wide survey of large rare copy number variants in Alzheimer's disease among Caribbean hispanics. G3 (Bethesda) 2, 71-78.

Gijselinck, I., van der Zee, J., Engelborghs, S., Goossens, D., Peeters, K., Mattheijssens, M., Corsmit, E., Del-Favero, J., De Deyn, P.P., Van Broeckhoven, C. Cruts, M., 2008. Progranulin locus deletion in frontotemporal dementia. Hum. Mutat. 29, 53-58.

Glessner, J.T., Li, J., Hakonarson, H., 2013. ParseCNV integrative copy number variation association software with quality tracking. Nucleic Acids Res. 41, e64.

Glessner, J.T., Wang, K., Cai, G., Korvatska, O., Kim, C.E., Wood, S., Zhang, H., Estes, A. Brune, C.W., Bradfield, J.P. Imielinski, M., Frackelton, E.C., Reichert, J. Crawford, E.L., Munson, J., Sleiman, P.M.A., Chiavacci, R., Annaiah, K., Thomas, K., Hou, C., Glaberson, W., Flory, J., Otieno, F., Garris, M., Soorya, L., Klei, L., Piven, J., Meyer, K.J., Anagnostou, E., Sakurai, T., Game, R.M., Rudd, D.S., Zurawiecki, D. McDougle, C.J., Davis, L.K., Miller, J., Posey, D.J., Michaels, S., Kolevzon, A., Silverman, J.M., Bernier, R., Levy, S.E., Schultz, R.T., Dawson, G., Owley, T. McMahon, W.M., Wassink, T.H., Sweeney, J.A., Nurnberger, J.I., Coon, H., Sutcliffe, J.S., Minshew, N.J., Grant, S.F.A., Bucan, M., Cook, E.H., Buxbaum, J.D. Devlin, B., Schellenberg, G.D., Hakonarson, H., 2009. Autism genome-wide copy number variation reveals ubiquitin and neuronal genes. Nature 459, 569-573.

Guerreiro, R., Brás, J., Hardy, J., 2015. SnapShot: genetics of ALS and FTD. Cell 160 798.e1.

Guerreiro, R., Brás, J., Hardy, J., 2013. SnapShot: genetics of Alzheimer's disease. Cell 155, 968-968.e1.

Guerreiro, R. Escott-Price, V. Darwent, L. Parkkinen, L, Ansorge, 0 , Hernandez, D.G., Nalls, M.A., Clark, L., Honig, L., Marder, K., van der Flier, W. Holstege, H., Louwersheimer, E., Lemstra, A., Scheltens, P., Rogaeva, E., St George-Hyslop, P., Londos, E., Zetterberg, H., Ortega-Cubero, S., Pastor, P., Ferman, T.J., Graff-Radford, N.R., Ross, O.A., Barber, I., Braae, A., Brown, K. Morgan, K., Maetzler, W., Berg, D., Troakes, C., Al-Sarraj, S., Lashley, T. Compta, Y., Revesz, T., Lees, A., Cairns, N.J., Halliday, G.M., Mann, D., PickeringBrown, S., Powell, J., Lunnon, K., Lupton, M.K., International Parkinson's Disease Genomics Consortium (IPDGC), Dickson, D., Hardy, J., Singleton, A., Bras, J., 2016. Genome-wide analysis of genetic correlation in dementia with Lewy bodies, Parkinson's and Alzheimer's diseases. Neurobiol. Aging 38, 214.e7-214.e10.

Guerreiro, R., Ross, O.A., Kun-Rodrigues, C., Hernandez, D.G., Orme, T., Eicher, J.D., Shepherd, C.E., Parkkinen, L., Darwent, L., Heckman, M.G., Scholz, S.W. Troncoso, J.C., Pletnikova, O., Ansorge, O., Clarimon, J., Lleo, A., MorenasRodriguez, E., Clark, L., Honig, L.S., Marder, K., Lemstra, A., Rogaeva, E., St George-Hyslop, P., Londos, E., Zetterberg, H., Barber, I., Braae, A., Brown, K. Morgan, K., Troakes, C., Al-Sarraj, S., Lashley, T., Holton, J., Compta, Y., Van Deerlin, V., Serrano, G.E., Beach, T.G., Lesage, S., Galasko, D., Masliah, E., Santana, I., Pastor, P., Diez-Fairen, M., Aguilar, M., Tienari, P.J., Myllykangas, L., Oinas, M., Revesz, T., Lees, A., Boeve, B.F., Petersen, R.C., Ferman, T.J., EscottPrice, V., Graff-Radford, N., Cairns, N.J., Morris, J.C., Pickering-Brown, S. Mann, D., Halliday, G.M., Hardy, J., Trojanowski, J.Q., Dickson, D.W., Singleton, A., Stone, D.J., Bras, J., 2018. Investigating the genetic architecture of dementia with Lewy bodies: a two-stage genome-wide association study. Lancet Neurol. 17, 64-74.

Guyant-Marechal, I., Berger, E., Laquerrière, A., Rovelet-Lecrux, A., Viennet, G. Frebourg, T., Rumbach, L., Campion, D., Hannequin, D., 2008. Intrafamilial diversity of phenotype associated with app duplication. Neurology 71, 1925-1926.

Hedrich, K., Eskelson, C., Wilmot, B., Marder, K., Harris, J., Garrels, J., MeijaSantana, H., Vieregge, P., Jacobs, H., Bressman, S.B., Lang, A.E., Kann, M. Abbruzzese, G., Martinelli, P., Schwinger, E., Ozelius, L.J., Pramstaller, P.P., Klein, C., Kramer, P., 2004. Distribution, type, and origin of Parkin mutations: review and case studies. Mov. Disord. 19, 1146-1157.

Heidebrink, J.L., 2002. Is dementia with Lewy bodies the second most common cause of dementia? J. Geriatr. Psychiatry Neurol. 15, 182-187.

Heinzen, E.L., Need, A.C., Hayden, K.M., Chiba-Falek, O., Roses, A.D., Strittmatter, W.J. Burke, J.R., Hulette, C.M., Welsh-Bohmer, K.A., Goldstein, D.B., 2010. Genomewide scan of copy number variation in late-onset Alzheimer's disease. J. Alzheimers. Dis. 19, 69-77.

Hepp, D.H., Vergoossen, D.L.E., Huisman, E., Lemstra, A.W., Netherlands Brain Bank, Berendse, H.W., Rozemuller, A.J., Foncke, E.M.J., van de Berg, W.D.J., 2016. Distribution and Load of amyloid- $\beta$ pathology in Parkinson disease and dementia with lewy bodies. J. Neuropathol. Exp. Neurol. 75, 936-945.

Ibáñez, P., Bonnet, A.-M., Débarges, B., Lohmann, E., Tison, F., Pollak, P., Agid, Y. Dürr, A., Brice, A., 2004. Causal relation between alpha-synuclein gene duplication and familial Parkinson's disease. Lancet 364, 1169-1171.

Ikeuchi, T., Kakita, A., Shiga, A., Kasuga, K., Kaneko, H., Tan, C.-F., Idezuka, J., Wakabayashi, K., Onodera, O., Iwatsubo, T., Nishizawa, M., Takahashi, H., Ishikawa, A., 2008. Patients homozygous and heterozygous for SNCA duplication in a family with parkinsonism and dementia. Arch. Neurol. 65, 514-519.

Jansen, I.E., Bras, J.M., Lesage, S., Schulte, C., Gibbs, J.R., Nalls, M.A., Brice, A. Wood, N.W., Morris, H., Hardy, J.A., Singleton, A.B., Gasser, T., Heutink, P. Sharma, M., IPDGC, 2015. CHCHD2 and Parkinson's disease. Lancet Neurol. 14 678-679.

Jarick, I., Volckmar, A.L., Pütter, C., Pechlivanis, S., Nguyen, T.T., Dauvermann, M.R. Beck, S., Albayrak, Ö., Scherag, S., Gilsbach, S., Cichon, S., Hoffmann, P. Degenhardt, F., Nöthen, M.M., Schreiber, S., Wichmann, H.-E., Jöckel, K.-H., Heinrich, J., Tiesler, C.M.T., Faraone, S.V., Walitza, S., Sinzig, J., Freitag, C., Meyer, J., Herpertz-Dahlmann, B., Lehmkuhl, G., Renner, T.J., Warnke, A Romanos, M., Lesch, K.P., Reif, A., Schimmelmann, B.G., Hebebrand, J. Scherag, A., Hinney, A., 2014. Genome-wide analysis of rare copy number 
variations reveals PARK2 as a candidate gene for attention-deficit/hyperactivity disorder. Mol. Psychiatry 19, 115-121.

Kay, D.M., Stevens, C.F., Hamza, T.H., Montimurro, J.S., Zabetian, C.P., Factor, S.A., Samii, A., Griffith, A., Roberts, J.W., Molho, E.S., Higgins, D.S., Gancher, S., Moses, L., Zareparsi, S., Poorkaj, P., Bird, T., Nutt, J., Schellenberg, G.D., Payami, H., 2010. A comprehensive analysis of deletions, multiplications, and copy number variations in PARK2. Neurology 75, 1189-1194.

Keogh, M.J., Kurzawa-Akanbi, M., Griffin, H., Douroudis, K., Ayers, K.L., Hussein, R.I., Hudson, G., Pyle, A., Cordell, H.J., Attems, J., McKeith, I.G., O’Brien, J.T., Burn, D.J., Morris, C.M., Thomas, A.J., Chinnery, P.F., 2016. Exome sequencing in dementia with Lewy bodies. Transl. Psychiatry 6, e728.

Khundakar, A.A., Hanson, P.S., Erskine, D., Lax, N.Z., Roscamp, J., Karyka, E., Tsefou, E., Singh, P., Cockell, S.J., Gribben, A., Ramsay, L., Blain, P.G., Mosimann, U.P., Lett, D.J., Elstner, M., Turnbull, D.M., Xiang, C.C., Brownstein, M.J., O’Brien, J.T., Taylor, J.-P., Attems, J., Thomas, A.J., McKeith, I.G., Morris, C.M., 2016. Analysis of primary visual cortex in dementia with Lewy bodies indicates GABAergic involvement associated with recurrent complex visual hallucinations. Acta Neuropathol. Commun. 4, 66.

Kim, S.Y., Seong, M.W., Jeon, B.S., Kim, S.Y., Ko, H.S., Kim, J.Y., Park, S.S., 2012. Phase analysis identifies compound heterozygous deletions of the PARK2 gene in patients with early-onset Parkinson disease. Clin. Genet. 82, 77-82.

Koide, T., Ohtake, H., Nakajima, T., Furukawa, H., Sakai, K., Kamei, H., Makifuchi, T., Fukuhara, N., 2002. A patient with dementia with Lewy bodies and codon 232 mutation of PRNP. Neurology 59, 1619-1621.

Labbé, C., Heckman, M.G., Lorenzo-Betancor, O., Soto-Ortolaza, A.I., Walton, R.L., Murray, M.E., Allen, M., Uitti, R.J., Wszolek, Z.K., Smith, G.E., Kantarci, K., Knopman, D.S., Lowe, V.J., Jack Jr., C.R., Ertekin-Taner, N., Hassan, A., Savica, R., Petersen, R.C., Parisi, J.E., Maraganore, D.M., Graff-Radford, N.R., Ferman, T.J., Boeve, B.F., Dickson, D.W., Ross, O.A., 2016. MAPT haplotype H1G is associated with increased risk of dementia with Lewy bodies. Alzheimers. Dement. 12, 1297-1304.

Le Guennec, K., Quenez, O., Nicolas, G., Wallon, D., Rousseau, S., Richard, A.-C., Alexander, J., Paschou, P., Charbonnier, C., Bellenguez, C., Grenier-Boley, B., Lechner, D., Bihoreau, M.-T., Olaso, R., Boland, A., Meyer, V., Deleuze, J.-F., Amouyel, P., Munter, H.M., Bourque, G., Lathrop, M., Frebourg, T., Redon, R., Letenneur, L., Dartigues, J.-F., Martinaud, O., Kalev, O., Mehrabian, S., Traykov, L., Ströbel, T., Le Ber, I., Caroppo, P., Epelbaum, S., Jonveaux, T., Pasquier, F., RollinSillaire, A. Génin, E., Guyant-Maréchal, L., Kovacs, G.G., Lambert, J.-C. Hannequin, D., Campion, D., Rovelet-Lecrux, A., 2017. 17q21.31 duplication causes prominent tau-related dementia with increased MAPT expression. Mol. Psychiatry 22, 1119-1125.

Lesage, S., Lohmann, E., Tison, F., Durif, F., Dürr, A., Brice, A., French Parkinson's Disease Genetics Study Group, 2008. Rare heterozygous parkin variants in French early-onset Parkinson disease patients and controls. J. Med. Genet. 45, 43-46.

Liu, X., Cheng, R., Ye, X., Verbitsky, M., Kisselev, S., Mejia-Santana, H., Louis, E., Cote, L., Andrews, H., Waters, C., Ford, B., Fahn, S., Marder, K., Lee, J., Clark, L., 2013. Increased rate of sporadic and recurrent rare genic copy number variants in Parkinson's disease among Ashkenazi Jews. Mol. Genet. Genomic Med. 1, 142-154.

Lladó, A., Rodríguez-Santiago, B., Antonell, A., Sánchez-Valle, R., Molinuevo, J.L., Reñé, R., Pérez-Jurado, L.A., 2007. MAPT gene duplications are not a cause of frontotemporal lobar degeneration. Neurosci. Lett. 424, 61-65.

MacDonald, J.R., Ziman, R., Yuen, R.K.C., Feuk, L., Scherer, S.W., 2014. The Database of Genomic Variants: a curated collection of structural variation in the human genome. Nucleic Acids Res. 42, D986-D992.

Marongiu, R., Brancati, F., Antonini, A., Ialongo, T., Ceccarini, C., Scarciolla, O., Capalbo, A., Benti, R., Pezzoli, G., Dallapiccola, B., Goldwurm, S., Valente, E.M., 2007. Whole gene deletion and splicing mutations expand the PINK1 genotypic spectrum. Hum. Mutat. 28, 98.

Marshall, C.R., Howrigan, D.P., Merico, D., Thiruvahindrapuram, B., Wu, W., Greer, D.S., Antaki, D., Shetty, A., Holmans, P.A., Pinto, D., Gujral, M., Brandler, W.M., Malhotra, D., Wang, Z., Fajarado, K.V.F., Maile, M.S., Ripke, S., Agartz, I., Albus, M., Alexander, M., Amin, F., Atkins, J., Bacanu, S.A., Belliveau Jr., R.A., Bergen, S.E., Bertalan, M., Bevilacqua, E., Bigdeli, T.B., Black, D.W., Bruggeman, R., Buccola, N.G., Buckner, R.L., Bulik-Sullivan, B., Byerley, W., Cahn, W., Cai, G., Cairns, M.J., Campion, D., Cantor, R.M., Carr, V.J., Carrera, N., Catts, S.V., Chambert, K.D., Cheng, W., Cloninger, C.R., Cohen, D., Cormican, P., Craddock, N., Crespo-Facorro, B., Crowley, J.J., Curtis, D., Davidson, M., Davis, K.L., Degenhardt, F., Del Favero, J., DeLisi, L.E., Dikeos, D., Dinan, T., Djurovic, S., Donohoe, G., Drapeau, E., Duan, J., Dudbridge, F., Eichhammer, P., Eriksson, J., Escott-Price, V., Essioux, L., Fanous, A.H., Farh, K.H., Farrell, M.S., Frank, J., Franke, L., Freedman, R., Freimer, N.B., Friedman, J.I., Forstner, A.J., Fromer, M., Genovese, G., Georgieva, L., Gershon, E.S., Giegling, I., Giusti-Rodríguez, P., Godard, S., Goldstein, J.I., Gratten, J., de Haan, L., Hamshere, M.L., Hansen, M., Hansen, T., Haroutunian, V., Hartmann, A.M., Henskens, F.A. Herms, S., Hirschhorn, J.N., Hoffmann, P. Hofman, A., Huang, H., Ikeda, M., Joa, I., Kähler, A.K., Kahn, R.S., Kalaydjieva, L., Karjalainen, J., Kavanagh, D., Keller, M.C., Kelly, B.J., Kennedy, J.L., Kim, Y., Knowles, J.A., Konte, B., Laurent, C., Lee, P., Lee, S.H., Legge, S.E., Lerer, B., Levy, D.L., Liang, K.-Y., Lieberman, J., Lönnqvist, J., Loughland, C.M., Magnusson, P.K.E., Maher, B.S., Maier, W., Mallet, J., Mattheisen, M., Mattingsdal, M., McCarley, R.W., McDonald, C., McIntosh, A.M., Meier, S., Meijer, C.J., Melle, I., Mesholam-Gately, R.I., Metspalu, A., Michie, P.T., Milani, L., Milanova, V., Mokrab, Y., Morris, D.W., Müller-Myhsok, B., Murphy, K.C., Murray, R.M., Myin-Germeys, I., Nenadic, I., Nertney, D.A., Nestadt, G.,
Nicodemus, K.K., Nisenbaum, L., Nordin, A., O'Callaghan, E., O’Dushlaine, C., Oh, S.-Y., Olincy, A., Olsen, L., O'Neill, F.A., Van Os, J., Pantelis, C., Papadimitriou, G.N., Parkhomenko, E., Pato, M.T., Paunio, T., Psychosis Endophenotypes International Consortium, Perkins, D.O., Pers, T.H., Pietiläinen, O. Pimm, J., Pocklington, A.J., Powell, J., Price, A., Pulver, A.E., Purcell, S.M. Quested, D., Rasmussen, H.B., Reichenberg, A., Reimers, M.A., Richards, A.L., Roffman, J.L., Roussos, P., Ruderfer, D.M., Salomaa, V., Sanders, A.R., Savitz, A. Schall, U., Schulze, T.G., Schwab, S.G., Scolnick, E.M., Scott, R.J., Seidman, L.J. Shi, J., Silverman, J.M., Smoller, J.W., Söderman, E., Spencer, C.C.A., Stahl, E.A., Strengman, E., Strohmaier, J., Stroup, T.S., Suvisaari, J., Svrakic, D.M. Szatkiewicz, J.P., Thirumalai, S., Tooney, P.A., Veijola, J., Visscher, P.M., Waddington, J., Walsh, D., Webb, B.T., Weiser, M., Wildenauer, D.B. Williams, N.M., Williams, S., Witt, S.H., Wolen, A.R., Wormley, B.K., Wray, N.R., Wu, J.Q., Zai, C.C., Adolfsson, R., Andreassen, O.A., Blackwood, D.H.R. Bramon, E., Buxbaum, J.D., Cichon, S., Collier, D.A., Corvin, A., Daly, M.J. Darvasi, A., Domenici, E., Esko, T., Gejman, P.V., Gill, M., Gurling, H., Hultman, C.M. Iwata, N., Jablensky, A.V. Jönsson, E.G., Kendler, K.S., Kirov, G. Knight, J., Levinson, D.F., Li, Q.S., McCarroll, S.A., McQuillin, A., Moran, J.L. Mowry, B.J., Nöthen, M.M., Ophoff, R.A., Owen, M.J., Palotie, A., Pato, C.N. Petryshen, T.L., Posthuma, D., Rietschel, M., Riley, B.P., Rujescu, D., Sklar, P., St Clair, D., Walters, J.T.R., Werge, T., Sullivan, P.F., O'Donovan, M.C., Scherer, S.W., Neale, B.M., Sebat, J., CNV and Schizophrenia Working Groups of the Psychiatric Genomics Consortium, 2017. Contribution of copy number variants to schizophrenia from a genome-wide study of 41,321 subjects. Nat. Genet. 49, 27-35.

Masliah, E., Rockenstein, E., Veinbergs, I., Sagara, Y., Mallory, M. Hashimoto, M., Mucke, L., 2001. $\beta$-Amyloid peptides enhance $\alpha$-synuclein accumulation and neuronal deficits in a transgenic mouse model linking Alzheimer's disease and Parkinson's disease. Proc. Natl. Acad. Sci. U. S. A 98, 12245-12250.

McCarthy, S.E., Makarov, V., Kirov, G., Addington, A.M., McClellan, J., Yoon, S., Perkins, D.O., Dickel, D.E., Kusenda, M., Krastoshevsky, O., Krause, V., Kumar, R.A., Grozeva, D., Malhotra, D., Walsh, T., Zackai, E.H., Kaplan, P. Ganesh, J., Krantz, I.D., Spinner, N.B., Roccanova, P., Bhandari, A., Pavon, K., Lakshmi, B., Leotta, A., Kendall, J., Lee, Y.-H., Vacic, V., Gary, S., Iakoucheva, L.M. Crow, T.J., Christian, S.L., Lieberman, J.A., Stroup, T.S., Lehtimäki, T., Puura, K., Haldeman-Englert, C., Pearl, J., Goodell, M., Willour, V.L., Derosse, P., Steele, J., Kassem, L., Wolff, J., Chitkara, N., McMahon, F.J., Malhotra, A.K., Potash, J.B., Schulze, T.G., Nöthen, M.M., Cichon, S., Rietschel, M., Leibenluft, E. Kustanovich, V., Lajonchere, C.M., Sutcliffe, J.S., Skuse, D., Gill, M., Gallagher, L. Mendell, N.R., Wellcome Trust Case Control Consortium, Craddock, N., Owen, M.J., O’Donovan, M.C., Shaikh, T.H., Susser, E., Delisi, L.E., Sullivan, P.F. Deutsch, C.K., Rapoport, J., Levy, D.L., King, M.-C., Sebat, J., 2009. Microduplications of 16 p11.2 are associated with schizophrenia. Nat. Genet. 41, 1223-1227.

McKeith, I.G., Boeve, B.F., Dickson, D.W., Halliday, G., Taylor, J.-P., Weintraub, D., Aarsland, D., Galvin, J., Attems, J., Ballard, C.G., Bayston, A., Beach, T.G., Blanc, F. Bohnen, N., Bonanni, L., Bras, J., Brundin, P., Burn, D., Chen-Plotkin, A., Duda, J.E., El-Agnaf, O., Feldman, H., Ferman, T.J., Ffytche, D., Fujishiro, H., Galasko, D. Goldman, J.G., Gomperts, S.N., Graff-Radford, N.R., Honig, L.S., Iranzo, A., Kantarci, K., Kaufer, D., Kukull, W., Lee, V.M.Y., Leverenz, J.B., Lewis, S., Lippa, C. Lunde, A., Masellis, M. Masliah, E. McLean, P., Mollenhauer, B., Montine, T.J. Moreno, E., Mori, E., Murray, M., O’Brien, J.T., Orimo, S., Postuma, R.B. Ramaswamy, S., Ross, O.A., Salmon, D.P., Singleton, A., Taylor, A., Thomas, A. Tiraboschi, P., Toledo, J.B., Trojanowski, J.Q., Tsuang, D., Walker, Z., Yamada, M., Kosaka, K., 2017. Diagnosis and management of dementia with Lewy bodies: Fourth consensus report of the DLB Consortium. Neurology 89, 88-100.

McKeith, I.G., Dickson, D.W., Lowe, J., Emre, M., O’Brien, J.T., Feldman, H. Cummings, J., Duda, J.E., Lippa, C., Perry, E.K., Aarsland, D., Arai, H., Ballard, C.G. Boeve, B., Burn, D.J., Costa, D., Del Ser, T., Dubois, B., Galasko, D., Gauthier, S. Goetz, C.G., Gomez-Tortosa, E., Halliday, G., Hansen, L.A., Hardy, J., Iwatsubo, T. Kalaria, R.N., Kaufer, D., Kenny, R.A., Korczyn, A., Kosaka, K., Lee, V.M.Y., Lees, A., Litvan, I., Londos, E., Lopez, O.L., Minoshima, S., Mizuno, Y., Molina, J.A., Mukaetova-Ladinska, E.B., Pasquier, F., Perry, R.H., Schulz, J.B., Trojanowski, J.Q. Yamada, M., Consortium on DLB, 2005. Diagnosis and management of dementia with Lewy bodies: third report of the DLB Consortium. Neurology 65, 1863-1872.

Meeus, B., Verstraeten, A., Crosiers, D., Engelborghs, S., Van den Broeck, M. Mattheijssens, M., Peeters, K., Corsmit, E., Elinck, E., Pickut, B., Vandenberghe, R., Cras, P., De Deyn, P.P., Van Broeckhoven, C., Theuns, J., 2012. DLB and PDD: a role for mutations in dementia and Parkinson disease genes? Neurobiol. Aging 33 629.e5-629.e18.

Mok, K.Y., Sheerin, U., Simón-Sánchez, I., Salaka, A., Chester, L., Escott-Price, V., Mantripragada, K., Doherty, K.M., Noyce, A.J., Mencacci, N.E., Lubbe, S.J., International Parkinson's Disease Genomics Consortium (IPDGC), WilliamsGray, C.H., Barker, R.A., van Dijk, K.D., Berendse, H.W., Heutink, P., Corvol, J.-C., Cormier, F., Lesage, S., Brice, A., Brockmann, K., Schulte, C., Gasser, T., Foltynie, T. Limousin, P., Morrison, K.E., Clarke, C.E., Sawcer, S., Warner, T.T., Lees, A.J. Morris, H.R., Nalls, M.A., Singleton, A.B., Hardy, J., Abramov, A.Y., Plagnol, V., Williams, N.M., Wood, N.W., 2016. Deletions at 22q11.2 in idiopathic Parkinson's disease: a combined analysis of genome-wide association data. Lancet Neurol. 15, 585-596.

Nalls, M.A., Duran, R., Lopez, G., Kurzawa-Akanbi, M., McKeith, I.G., Chinnery, P.F., Morris, C.M., Theuns, J., Crosiers, D., Cras, P., Engelborghs, S., De Deyn, P.P., Van Broeckhoven, C., Mann, D.M.A., Snowden, J., Pickering-Brown, S., Halliwell, N., 
Davidson, Y., Gibbons, L., Harris, J., Sheerin, U.-M., Bras, J., Hardy, J., Clark, L., Marder, K., Honig, L.S., Berg, D., Maetzler, W., Brockmann, K., Gasser, T., Novellino, F., Quattrone, A., Annesi, G., De Marco, E.V., Rogaeva, E., Masellis, M., Black, S.E., Bilbao, J.M., Foroud, T., Ghetti, B., Nichols, W.C., Pankratz, N., Halliday, G., Lesage, S., Klebe, S., Durr, A., Duyckaerts, C., Brice, A., Giasson, B.I., Trojanowski, J.Q., Hurtig, H.I., Tayebi, N., Landazabal, C., Knight, M.A., Keller, M., Singleton, A.B., Wolfsberg, T.G., Sidransky, E., 2013. A multicenter study of glucocerebrosidase mutations in dementia with Lewy bodies. JAMA Neurol. 70, $727-735$.

Need, A.C., Ge, D., Weale, M.E., Maia, J., Feng, S., Heinzen, E.L., Shianna, K.V., Yoon, W., Kasperaviciūte, D., Gennarelli, M., Strittmatter, W.J., Bonvicini, C., Rossi, G., Jayathilake, K., Cola, P.A., McEvoy, J.P., Keefe, R.S.E., Fisher, E.M.C., St Jean, P.L., Giegling, I., Hartmann, A.M., Möller, H.-J., Ruppert, A., Fraser, G., Crombie, C., Middleton, L.T., St Clair, D., Roses, A.D., Muglia, P., Francks, C., Rujescu, D., Meltzer, H.Y., Goldstein, D.B., 2009. A genome-wide investigation of SNPs and CNVs in schizophrenia. Plos Genet. 5, e1000373.

Nishioka, K. Hayashi, S., Farrer, M.J., Singleton, A.B., Yoshino, H., Imai, H., Kitami, T., Sato, K., Kuroda, R., Tomiyama, H., Mizoguchi, K., Murata, M., Toda, T., Imoto, I., Inazawa, J., Mizuno, Y., Hattori, N., 2006. Clinical heterogeneity of alphasynuclein gene duplication in Parkinson's disease. Ann. Neurol. 59, 298-309.

Obi, T., Nishioka, K., Ross, O.A., Terada, T., Yamazaki, K., Sugiura, A., Takanashi, M., Mizoguchi, K., Mori, H., Mizuno, Y., Hattori, N., 2008. Clinicopathologic study of a SNCA gene duplication patient with Parkinson disease and dementia. Neurology 70, 238-241.

Ohtake, H., Limprasert, P., Fan, Y., Onodera, O., Kakita, A., Takahashi, H., Bonner, L.T., Tsuang, D.W., Murray, I.V.J., Lee, V.M.-Y., Trojanowski, J.Q., Ishikawa, A., Idezuka, J., Murata, M., Toda, T., Bird, T.D., Leverenz, J.B., Tsuji, S., La Spada, A.R., 2004. Beta-synuclein gene alterations in dementia with Lewy bodies. Neurology 63, 805-811.

Pankratz, N., Dumitriu, A., Hetrick, K.N., Sun, M., Latourelle, J.C., Wilk, J.B., Halter, C., Doheny, K.F., Gusella, J.F., Nichols, W.C., Myers, R.H., Foroud, T., DeStefano, A.L., PSG-PROGENI and GenePD Investigators, Coordinators and Molecular Genetic Laboratories, 2011. Copy number variation in familial Parkinson disease. PLoS One 6, e20988.

Perrone, F., Nguyen, H.P., Van Mossevelde, S., Moisse, M., Sieben, A., Santens, P., De Bleecker, J., Vandenbulcke, M., Engelborghs, S., Baets, J., Cras, P., Vandenberghe, R., De Jonghe, P., De Deyn, P.P., Martin, J.-J., Van Damme, P., Van Broeckhoven, C., van der Zee, J., Belgian Neurology consortium, 2017. Investigating the role of ALS genes CHCHD10 and TUBA4A in Belgian FTD-ALS spectrum patients. Neurobiol. Aging 51, 177.e9-177.e16.

Peuralinna, T., Myllykangas, L., Oinas, M., Nalls, M.A., Keage, H.A.D., Isoviita, V.-M., Valori, M., Polvikoski, T., Paetau, A., Sulkava, R., Ince, P.G., Zaccai, J., Brayne, C., Traynor, B.J., Hardy, J., Singleton, A.B., Tienari, P.J., 2015. Genome-wide association study of neocortical Lewy-related pathology. Ann. Clin. Transl Neurol. 2, 920-931.

Rovelet-Lecrux, A., Hannequin, D., Guillin, O., Legallic, S., Jurici, S., Wallon, D., Frebourg, T., Campion, D., 2010. Frontotemporal dementia phenotype associated with MAPT gene duplication. J. Alzheimers. Dis. 21, 897-902.

Rovelet-Lecrux, A., Lecourtois, M., Thomas-Anterion, C., Le Ber, I., Brice, A., Frebourg, T., Hannequin, D., Campion, D., 2009. Partial deletion of the MAPT gene: a novel mechanism of FTDP-17. Hum. Mutat. 30, E591-E602.

Saitoh, T., Xia, Y., Chen, X., Masliah, E., Galasko, D., Shults, C., Thal, L.J., Hansen, L.A., Katzman, R., 1995. The CYP2D6B mutant allele is overrepresented in the Lewy body variant of Alzheimer's disease. Ann. Neurol. 37, 110-112.

Santpere, G., Garcia-Esparcia, P., Andres-Benito, P., Lorente-Galdos, B., Navarro, A., Ferrer, I., 2018. Transcriptional network analysis in frontal cortex in Lewy body diseases with focus on dementia with Lewy bodies. Brain Pathol. 28, 315-333.

Simon-Sanchez, J., Scholz, S., Fung, H.-C., Matarin, M., Hernandez, D., Gibbs, J.R., Britton, A., de Vrieze, F.W., Peckham, E., Gwinn-Hardy, K., Crawley, A., Keen, J.C., Nash, J., Borgaonkar, D., Hardy, J., Singleton, A., 2007. Genome-wide SNP assay reveals structural genomic variation, extended homozygosity and cell-line induced alterations in normal individuals. Hum. Mol. Genet. 16, 1-14.
Skoglund, L., Ingvast, S., Matsui, T., Freeman, S.H., Frosch, M.P., Brundin, R. Giedraitis, V., Growdon, J.H., Hyman, B.T., Lannfelt, L., Ingelsson, M., Glaser, A., 2009. No evidence of PGRN or MAPT gene dosage alterations in a collection of patients with frontotemporal lobar degeneration. Dement. Geriatr. Cogn. Disord. $28,471-475$.

Sleegers, K., Brouwers, N., Gijselinck, I., Theuns, J., Goossens, D., Wauters, J., DelFavero, J., Cruts, M., van Duijn, C.M., Van Broeckhoven, C., 2006. APP duplication is sufficient to cause early onset Alzheimer's dementia with cerebral amyloid angiopathy. Brain 129, 2977-2983.

Spillantini, M.G., Schmidt, M.L., Lee, V.M., Trojanowski, J.Q., Jakes, R., Goedert, M., 1997. Alpha-synuclein in lewy bodies. Nature 388, 839-840.

Stefansson, H., Rujescu, D., Cichon, S., Pietiläinen, O.P.H., Ingason, A., Steinberg, S., Fossdal, R., Sigurdsson, E., Sigmundsson, T., Buizer-Voskamp, J.E., Hansen, T., Jakobsen, K.D., Muglia, P., Francks, C., Matthews, P.M., Gylfason, A. Halldorsson, B.V., Gudbjartsson, D., Thorgeirsson, T.E., Sigurdsson, A., Jonasdottir, A., Jonasdottir, A., Bjornsson, A., Mattiasdottir, S., Blondal, T., Haraldsson, M., Magnusdottir, B.B., Giegling, I., Möller, H.-J., Hartmann, A. Shianna, K.V., Ge, D., Need, A.C., Crombie, C., Fraser, G., Walker, N., Lonnqvist, J., Suvisaari, J., Tuulio-Henriksson, A., Paunio, T., Toulopoulou, T., Bramon, E., Di Forti, M., Murray, R., Ruggeri, M., Vassos, E., Tosato, S., Walshe, M., Li, T., Vasilescu, C., Mühleisen, T.W., Wang, A.G., Ullum, H., Djurovic, S., Melle, I. Olesen, J., Kiemeney, L.A., Franke, B., GROUP, Sabatti, C., Freimer, N.B., Gulcher, J.R., Thorsteinsdottir, U., Kong, A., Andreassen, O.A., Ophoff, R.A., Georgi, A., Rietschel, M., Werge, T., Petursson, H., Goldstein, D.B., Nöthen, M.M. Peltonen, L., Collier, D.A., St Clair, D., Stefansson, K., 2008. Large recurrent microdeletions associated with schizophrenia. Nature 455, 232-236.

Swaminathan, S., Kim, S., Shen, L., Risacher, S.L., Foroud, T., Pankratz, N., Potkin, S.G., Huentelman, M.J., Craig, D.W., Weiner, M.W., Saykin, A.J., The Alzheimer's Disease Neuroimaging Initiative Adni, 2011. Genomic copy number analysis in Alzheimer's disease and Mild Cognitive Impairment: an ADNI study. Int. J. Alzheimers. Dis. 2011, 729478.

Swaminathan, S., Shen, L., Kim, S., Inlow, M., West, J.D., Faber, K.M., Foroud, T., Mayeux, R. Saykin, A.J., Alzheimer's Disease Neuroimaging Initiative, NIA-LOAD/NCRAD Family Study Group, 2012. Analysis of copy number variation in Alzheimer's disease: the NIALOAD/NCRAD Family Study. Curr. Alzheimer Res. 9, 801-814.

Wang, K., Li, M., Hadley, D., Liu, R., Glessner, J., Grant, S.F.A., Hakonarson, H. Bucan, M., 2007. PennCNV: an integrated hidden Markov model designed for high-resolution copy number variation detection in whole-genome SNP genotyping data. Genome Res. 17, 1665-1674.

Waters, C.H., Miller, C.A., 1994. Autosomal dominant Lewy body parkinsonism in a four-generation family. Ann. Neurol. 35, 59-64.

Webb, J.L., Ravikumar, B., Atkins, J., Skepper, J.N., Rubinsztein, D.C., 2003. AlphaSynuclein is degraded by both autophagy and the proteasome. J. Biol. Chem. 278, 25009-25013.

Weiss, L.A., Shen, Y., Korn, J.M., Arking, D.E., Miller, D.T., Fossdal, R., Saemundsen, E., Stefansson, H., Ferreira, M.A.R., Green, T., Platt, O.S., Ruderfer, D.M., Walsh, C.A., Altshuler, D., Chakravarti, A., Tanzi, R.E., Stefansson, K., Santangelo, S.L. Gusella, J.F., Sklar, P., Wu, B.-L., Daly, M.J., Autism Consortium, 2008. Association between microdeletion and microduplication at 16p11.2 and autism. N. Engl. J. Med. 358, 667-675.

Zhang, M., Xi, Z., Zinman, L., Bruni, A.C., Maletta, R.G., Curcio, S.A.M., Rainero, I., Rubino, E., Pinessi, L., Nacmias, B., Sorbi, S., Galimberti, D., Lang, A.E., Fox, S. Surace, E.I., Ghani, M., Guo, J., Sato, C., Moreno, D., Liang, Y., Keith, J., Traynor, B.J., St George-Hyslop, P., Rogaeva, E., 2015. Mutation analysis of CHCHD10 in different neurodegenerative diseases. Brain 138, e380.

Zheng, X., Demirci, F.Y., Barmada, M.M., Richardson, G.A., Lopez, O.L., Sweet, R.A. Kamboh, M.I., Feingold, E., 2015. Genome-wide copy-number variation study of psychosis in Alzheimer's disease. Transl. Psychiatry 5, e574.

Zheng, X., Demirci, F.Y., Barmada, M.M., Richardson, G.A., Lopez, O.L., Sweet, R.A Kamboh, M.I., Feingold, E., 2014. A rare duplication on chromosome 16 p11.2 is identified in patients with psychosis in Alzheimer's disease. PLoS One 9 e111462. 